\title{
A STUDY TO IDENTIFY TALENT DEVELOPMENT PRACTICES IN THE HOSPITALITY SECTOR AND ITS IMPACT ON ORGANIZATIONAL PERFORMANCE
}

\author{
Rajeev Ranjan MISHRA* \\ Amity University Uttar Pradesh, Faculty of Hospitality \& Tourism, \\ Sector-125, Noida, India, e-mail: rajeevmishra1976@rediffmail.com \\ Piyush SHARMA \\ Amity University Uttar Pradesh, Faculty of Hospitality \& Tourism, \\ Sector-125, Noida, India, e-mail: psharma3@amity.edu \\ Sanjeev KUMAR \\ IHTM, Maharshi Dayanand University, Rohtak, Haryana \\ 124001, Rohtak, India, e-mail: sanjeev.rawal30@gmail.com
}

\begin{abstract}
Citation: Mishra, R.R., Sharma, P., \& Kumar, S. (2019). A STUDY TO IDENTIFY TALENT DEVELOPMENT PRACTICES IN THE HOSPITALITY SECTOR AND ITS IMPACT ON ORGANIZATIONAL PERFORMANCE. GeoJournal of Tourism and Geosites, 26(3), 861-873. https://doi.org/10.30892/gtg.26315-403
\end{abstract}

\begin{abstract}
This study aims to identify the talent development practices adopted by hospitality industry and its impact on their performance. The study has been based on empirical and secondary data collected from 70 luxury and budget hotels across seven countries in Asian region. Research showed that there are mainly five talent development practices out of 25, which are prevailing in both the luxury and budget hotels. These practices are mainly training \& development, career development, performance appraisal, mentoring and recognitions and award. Further it was found from the regression analysis that, out of these five, only career development and performance appraisal practices were found to have a significant and positive impact on the organizational performance of the hospitality industry which has been measured in terms of ROA, ROE and growth in guest arrival in hotels during last five years.
\end{abstract}

Keywords: Talent development, organizational performance, hospitality, tourism, hotel, management, Asia, training and development

\section{INTRODUCTION}

The hospitality industry is among the fastest developing sector across the globe. According to the World Travel and Tourism Council, travel and tourism GDP makes up for more than one-tenth of the world's GDP and is also offering employment

\footnotetext{
* Corresponding author
} 
opportunities at a huge scale. The hotels, restaurants and other institutions that make up the hospitality sector are ultimately important not merely in generating direct revenue for local economies, but also indirectly building the economies, through promotion of business, infrastructure and the regional status of a nation in the global scheme of things. In India, hospitality sector accounts for a healthy $7.5 \%$ of the country's GDP, making it a highly influential industry (Malhotra, 2017). It is a major attraction for foreign direct investment into the country's economic growth and also a significant contributor to indirect tax collection at both state and central levels.

The quality of hospitality sector arises purely from the quality of its employment of human resource. It results in the need to pay attention to the talent and skill of employees that are recruited to work in the industry. In the present age, globalization and significant population migration have created talent wars across sectors and countries. Researchers have found that organizations are vying for the same pool of talents across the globe (Michaels et al., 2001). This competition for the most talented employees can give way to unethical business practices such as poaching. In fact, many organizations stand in the risk of losing their best talents to their rivals, leaving them in the unenviable position of starting all over again with training other employees or finding ways to tempt new talent into their fold (Brewster et al., 2007). It must be kept in mind that the entire growth of the hospitality industry is assumed on the availability, volume and quality of good talent along with the surety of retaining it within the sector. Thus there is a great need for talent in the hospitality industry all over the globe. Challenges that arise in search and sustenance of good talent are critical in bringing a boost in organizational performance and future success (Singh, 2018).

These deficiencies and lags in talent procurement and management have detrimental effects on the organizational performance. These gaps leave their shadow on important organizational factors like operating costs, bottom- line profitability, service, brand quality, and future growth. Organizations are waking up to the fact that talent needs to be introduced as well as nurtured to bring optimum growth of performance; talent must be developed through well- crafted exercises and practices. Talent development strategies attract and enhance talent that is best suited for organizational goals and aspirations. Over the years, these practices have been witnessed to achieve great results. The benefits of an efficient talent development practice can include better recruitment and retention rates and greater employee participation (Lewis \& Heckman, 2006). While in the era of 1980s the HR agency was limited to the roles of administrative or supportive functions only, the 1990s saw a shift in the favour of HR industry being seen as strategically vital for organizational growth (Singh, 2018). This change in scenario and business perspective has brought the significance of human resources to the front. The war for talent that exists in the world is being dearly fought at every step, and employees with the talents of specialization, expertise and skill are considered as golden resources to be valued and encouraged.

The strategic importance of talented employees now poses to be key determinant in the company's decisions on design, development and delivery of a strategy. Not only talented employees, but talented managers and executives are also seen as a precious and valuable resource for an organization, which is proved by the global race to bring the best managers and recruiters to hire the talent that boosts the performance of the organization (Ford et al., 2010). This fact only stresses the importance of this topic to be studied and discussed at length. In the hospitality sector, job opportunities are vast and demanding, and talented employees are treated as a major asset and the primary source of competitive advantage (Frank et al., 2004). It then becomes vital to analyse the real 
effectiveness of talent development practices adopted by employers and managers on the organizational performance in the hospitality sector. The talent development practices are wide and varied in the industry. There is a need in research to identify the most commonly prevailing practices and strategies used to develop and nurture talents among employees, and analyse their impact on overall organizational performance.

\section{OBJECTIVE}

1. To identify the talent development practices adopted for middle management by luxury hotels

and budget hotels of selected Asian countries.

2. To measure and compare the effectiveness of talent development practices in luxury and budget hotels of selected Asian countries.

3. To measure the impact of talent development practices on the organizational performance of luxury hotels as well as budget hotels of selected Asian countries.

\section{REVIEW OF LITERATURE}

The discussion on talent development practices and their impacts cannot begin without understanding the meaning of the word 'talent'. According to Iles et al., (2010) and Kim et al., (2012) the concept of talent has been of great interest to researchers and practitioners alike over the last two decades. Talent can be described in brief as the euphemism for people (Nilsson \& Ellstrom, 2012) and in corporate sector, it is seen in economic perspective as human capital, assets or market value of a worker for contribution to the organization (Brown \& Tannock, 2009).

According to Baum (2015) hotels rely a lot on low skilled or unskilled workers; and thus the lack of clarity of the concept of talent is more 'pronounced' within this industry. However, it may be defined, there is no doubt about the fact that talent is an essential cog in running a company, and has a central importance in the hospitality industry which is service intensive and has a peculiar employment structure challenged too often by problems in employee retention. It is this essentiality of talent in hospitality sector that demands its development and nourishment for positive outcomes. The concept of talent development and management is increasingly discussed in literature (Stahl et al., 2007, Scullion et al., 2011, Berger \& Berger, 2003). It has been said to have imperative role to play in any industry (Barlow, 2006).

It is understood to include all stages of bringing and growing talent within an organization, from sourcing of new talent and screening it for suitable purpose, to retention and deployment of the employees in the organization (McDonnell, 2011). The management of human resource involves management of individual skills and abilities (Nilsson \& Ellstrom, 2012). Cascio (2015) defined talent development as the science of using strategic HR to improve business value and make it possible for companies and organizations to reach their goals. Sumardi and Othman (2009) gave two approaches to talent development namely the exclusive approach which includes selection of a group of managers for special attention and secondly, the alternative approach which was more inclusive in nature and focused on developing all managers. Talent development is a very complex and fraught activity (Barlow, 2016). Standardized approaches that operate on assumptions of similarities between talented people often do not work very effectively. Talented people are capable of being high performing contributors to an organization but need support from the management. Therefore, talent development should form an integral part of the central activities underlying human resource management. As per Garavan (2012), talent development is a focus on the plan, 
selection and implementation of development practices for the workforce in the organization to meet the pre-set objectives (Maycock \& Ikuomola, 2015).

As per McCauley and Douglas (2004), talent development practices can be of five categories namely developmental relationships, assignments, feedback systems, formal programs and individual self- development methods. Developmental relationships are about fostering talent through creating artificial relationships such as mentoring and coaching to encourage learning and growth of skill. Developmental assignments include career progression through strategic promotions and other encouraging methods.

Feedback systems develop talent through establishing a structure of checks and balances, and pointing inconsistencies and smoothing them out for stabilizing talent development. Formal programs include training and preparation for a newer set of challenging tasks at work. Lastly, individual self- development methods are made up of activities like surplus reading and practice that is encouraged through the establishment of either physical structures like libraries, or amenities like incentive bonuses. These practices pertain to ensuring internal consistency of the talent employed at the organization (internal fit) and are incorporated into company's culture (cultural fit) after ensuring their alignment with the company's goals and purposes (strategic fit). The combination of these three criteria then creates an inimitable system of practices and not only drives excellence in talent development but also contributes to organizational learning and knowledge management (Singh, 2018).

Thus, it is evident that talent development practices are an essential portion of human resource management in any organization. The crisis for talented employees has struck the corporate world only today, due to the changing scenario of workforce in the present era. The newer generations are witnessed to have a particular set of attitudes and work behaviours that are vastly different as compared to older generations which are set to retire and have their own demands accordingly (Magd, 2003) especially in the hospitality sector (Barlow, 2014). The present study shall answer questions that have been relatively unexplored in the wealth of literature available in this regard. The researchers have strived to identify commonly practiced talent development practices in the hospitality sector, and the impact on organizational performance.

\section{RESEARCH GAPS}

In the literature reviewed above, it can be seen that talent development has been very widely and varyingly defined but not many structured or quantitative studies seem to have been undertaken in the domain of talent development practices adopted by hotels through a comparative study in luxury hotels and budget hotels.

Another unexplored area in this field of research has been the relative impact of the various practices of talent development on the performance of hotels. The present study gains direction from the above cited gaps, and intends to explore further on the existing talent development practices and the challenges faced by organization and the employees in heading towards a talent ship based structure.

\section{RESEARCH METHODOLOGY}

The present paper is a study in the effect of talent and development practices upon organizational performance of an institution under the hospitality and tourism sector, especially in Asia. The researchers have derived from both primary and secondary sources of data to achieve the objectives of the study. Secondary data related to three parameters used for organizational performance have been collected from the annual reports and the financial statements of the hotels surveyed during current study. The period of the data 
was from 2012 to 2017. Primary data was also collected from the employees and professionals working in the hospitality sector towards the perceived effectiveness of talent development practices in their organization, through face to face interactions, emails and through web sessions. The study has been conducted across a total of 70 hotels across major countries in Asia namely, India, Malaysia, Maldives, Thailand, Sri Lanka, Singapore and Indonesia. The hotels so surveyed included 35 luxury hotels and 35 budget hotels as well. This distinction was included to ensure a universal applicability of the study across different standards or types of hotels in the industry.

\section{FINDINGS AND DISCUSSIONS}

This section has been divided into three sections. First section discusses about the talent development practices prevailing in hotels, second section discusses the results related to the effectiveness of the talent development practices and third section comprises the results related to the impact of effectiveness of talent development practices on organizational performance.

\section{Talent development Practices Prevailing in Hotels}

Researchers have found the frequency of occurrence of common talent development practices across 35 luxury and 35 budget hotels from seven south- Asian countries that were chosen for the survey. The study includes data on 25 widely identified talent development practices like training and development of employees, mentoring, performance appraisals, team development and relationship management.

The researchers have collected data on which practices are prevalent among the surveyed hotels, both of luxury and budget types. This was done with the objective of identifying most commonly employed practices and techniques of talent development that prevailed across the surveyed hotels. The data thus collected reveals five most pervasive practices of talent development and development in the tourism and hospitality sector. These practices were training and development of employees, career development opportunities, performance appraisal at regular intervals, proper mentoring, and recognition and awards for encouraging talented employees.

These five techniques have been found to be positively practiced at all surveyed hotels of both luxury and budget status. All hotels across the surveyed countries have utilized these practices for the development of their employees. These can thus be concluded as most highly effective practices for talent development in the tourism and hospitality sector, regardless of geographical or political boundaries and kinds of services or status. With such maximum frequency and application of these practices, it follows that these practices also have a substantial impact on the organizational efficiency of any hospitality institution in managing their human talent resources.

\section{Effectiveness of Talent development practices}

The objective was to ascertain the most effective practices for talent development in the tourism and hospitality sector that is widely accepted across both luxury and budget hotels. Where majority of the hoteliers showed favour to a particular practice, it was understood to be an effective practice for developing good talent in the industry.

Several practices were identified in this manner to be best suited for the management and development of talent in the tourism or hospitality sector. Training and development practices for employees, especially for newer recruitments, were placed very highly in the list of favoured practices by hoteliers. Another practice that was found to be effective in the eyes of the hotel employees and managers was performance appraisal at regular intervals. This practice boosted talent through necessary re-evaluations by the organization managers. However, the practice of 
continuous feedback received mixed response from the surveyed respondents in the survey. This implies that while timely performance appraisals are welcome and beneficial to improving organizational efficiency, very frequent or continuous feedback techniques could be detrimental to the objective of nurturing and developing talent.

Opportunities for career development when provided to employees could also have a major impact in encouraging talent and improving the efficacy of the organization. Employers that recognize the desire for job success and career growth are successful in developing talent and managing the human resource. Employers and HR managers can have a direct and key role to play in the development of talent. The practice of mentorship and guidance towards employees was found to be an effective technique to help in talent development in the hospitality sector. The respondent hoteliers also shed light on inefficient practices that do not create a substantial ripple in talent development. A very commonly used practice of recognition and awards for good performance was found to be not very effective in development of talent and by relation, boosting organizational efficiency. While a good number of hoteliers expressed favour towards its effectiveness, the majority of the respondents did not agree with the view, or were neutral about the same. This indicates that financial rewards or recognition were not very effectual in developing talent in employees across hospitality sector.

Table 1. Effectiveness of Talent Development Practices in Luxury and Budget Hotels

\begin{tabular}{|c|c|c|c|c|c|}
\hline $\begin{array}{l}\text { Sr. } \\
\text { No. }\end{array}$ & Practice/ Method & \begin{tabular}{|c|} 
Luxury Hotels \\
Mean
\end{tabular} & \begin{tabular}{|c|} 
Budget Hotels \\
Mean
\end{tabular} & F-value & p-value \\
\hline 1 & Training and development & 3.74 & 2.06 & 43.038 & .000 \\
\hline 2 & Career Development & 3.94 & 2.17 & 65.676 & .000 \\
\hline 3 & Performance Appraisal & 3.94 & 2.31 & 59.073 & .000 \\
\hline 4 & Exit Interviews & 3.89 & 2.29 & 51.910 & .000 \\
\hline 5 & Compensation Management & 3.77 & 2.17 & $45 \cdot 372$ & .000 \\
\hline 6 & Mentoring & 3.74 & 2.29 & 28.768 & .000 \\
\hline 7 & Recognition and Award & 3.77 & 2.34 & 26.967 & .000 \\
\hline 8 & Differential/ Outrageous Benefits & 3.77 & 2.11 & 40.995 & .000 \\
\hline 9 & Limited- term employee contracts & 3.89 & 2.23 & 43.161 & .000 \\
\hline 10 & Employee referrals & 3.97 & 2.31 & 45.065 & .000 \\
\hline 11 & Goals Alignment with the organization & 4.63 & 2.23 & 147.906 & .000 \\
\hline 12 & Continuous feedback & 4.66 & 2.43 & 171.522 & .000 \\
\hline 13 & Team Strengthening & 4.63 & 2.57 & 153.801 & .000 \\
\hline 14 & HR/ Talent analytics & 4.49 & 2.71 & 77.981 & .000 \\
\hline 15 & Consolidation of staff requirements & 4.40 & 2.69 & 92.169 & .000 \\
\hline 16 & Identification of talent gaps & 4.74 & 2.60 & 139.803 & .000 \\
\hline 17 & Managed recruiting process & 2.94 & 1.40 & 58.665 & .000 \\
\hline 18 & Internal sourcing & 3.40 & 1.89 & 62.098 & .000 \\
\hline 19 & Pre- hire assessment & 3.40 & 1.91 & 60.885 & .000 \\
\hline 20 & University/ college recruiting & 3.29 & 2.03 & 55.129 & .000 \\
\hline 21 & Employer branding & 3.17 & 1.94 & 48.733 & .000 \\
\hline 22 & Diversified workforce & 3.40 & 1.91 & 55.719 & .000 \\
\hline 23 & Relationship Management & 3.40 & 1.86 & 58.183 & .000 \\
\hline 24 & Accrued time-off for relaxation and creativity & 3.77 & 1.17 & 276.033 & .000 \\
\hline 25 & Succession Management & 3.83 & 1.77 & 217.600 & .000 \\
\hline
\end{tabular}

Several practices for talent development were seen to be effective in varying degrees in luxury hotels in comparison with budget hotels, proving that the type of hotel 
or organization has an impact on the effectiveness of talent development practices. In practices pertaining to training and development or mentoring of the employees, it was revealed that luxury hotels have a higher success rate than budget hotels. Similarly, in terms of providing recognition for good work and appreciative awards to talented employees, luxury hotels performed better than budget hotels in achieving a resultant growth in organizational performance. In the case of career development and performance appraisal practices, it was found that luxury hotels found the practices very effective for the organization. However, the biggest difference between the effectiveness of practices in luxury and budget hotels was found in the case of practices that tended to bring the employees interests in tune with the organizational aims. These practices included alignment of individual growth goals with the company's objectives, and strengthening teamwork in the entire organization. The data in its entirety then shows that talent development practices are more effective in general in luxury hotels in contrast to the budget hotels. Luxury hotels employ a great number of employees, and have wellformed mechanisms in place to ensure proper conduction of talent development practices. This is usually done through specific departments set aside for human resource management. In budget hotels, however, the workforce population is small in size and is often managed by either the owner of the hotel or a general manager that oversees the entire functioning of the hotel. Thus, luxury hotel derives greater effectiveness from talent development practices than budget hotels because of the availability of specialists and established structure for implementation of these practices.

\section{Talent development practices and organizational performance}

The researchers have formulated five hypotheses according to the exclusive relationship between each significant talent development practice and the impact on organizational efficiency in the hospitality sector.

Table 2. Talent development practices and organizational performance

\begin{tabular}{|l|c|c|c|}
\hline Regression Model Summary & ROA & ROE & (Growth rate in guest arrival \\
\hline R-value & 0.909 & 0.526 & 0.840 \\
\hline R-square & 0.827 & 0.275 & 0.706 \\
\hline Adjusted R-square & 0.814 & 0.218 & 0.683 \\
\hline Anova Value & 61.246 & 4.855 & 30.737 \\
\hline p-value & 0.000 & 0.001 & 0.000 \\
\hline Constant & -7.982 & -0.245 & -6.778 \\
\hline Training and development & $0.511^{* *}$ & 0.152 & $0.530^{* *}$ \\
\hline Career Development & $0.364^{* *}$ & $0.310^{* *}$ & $0.368^{* *}$ \\
\hline Performance Appraisal & $0.320^{* *}$ & $0.288^{* *}$ & $0.316^{* *}$ \\
\hline Mentoring & $0.124^{* *}$ & 0.081 & 0.018 \\
\hline Recognition and Award & 0.077 & 0.117 & 0.010 \\
\hline
\end{tabular}

The organizational performance in the present study has been measured using three dependent variables namely; return on assets (ROA), return on equity (ROE) and growth in guest arrival over five years from 2012- 2017. The regression models considered in the study were applied to five practices that were identified as the most commonly adopted by all the seventy hotels surveyed in the study, including thirty- five luxury and thirty-five budget hotels, across selected Asian countries. The five practices namely, training and development, career development, performance appraisal, mentoring and recognition and awards, have been taken as independent variables in the model. The researchers have applied three different regression models in this study to measure the 
relationship between talent development practices and their impact on organizational performance as a whole. Results showed that five major talent development practices explain 82 \% variation in the value of Return on Asset, $27 \%$ variation in the Return on Equity and $70 \%$ variation in the Growth in guest arrival. Further, it was found that career development and performance appraisal are two key talent development practices which were found to be significantly related to all the three parameters used to measure the organizational performance of the luxury and budget hotels of Asia.

Hypothesis 1: There is no significant impact of training and development practices on the organizational performance of hospitality sector.

Training and development practices of luxury and budget hotel was found to be significantly and positively related to the Return on Assets, and Growth in guest arrival while it was found to have an insignificant relationship with the Return on equity. Thus the null hypothesis is rejected and it can be said that there is a significant impact of training and development practices on the organizational performance of hospitality sector in the region. Organizations use the practice of specific training and developmental programs to hone special set of skills or talent within the workforce.

This development method is characterized by attendance to corporate programs, executive education and formal education (Garavan et al., 2011). It is important to invest in human resources through training (Nafukho, 2004) in order to improve the competitive position of the firm. Training and developmental practices are programs other than that meant for career advancement, however. They are not intended as a step up in the hierarchy of power structure in an organization, but rather meant simply to introduce newer talents or develop existing ones to better quality. Training presents a prime opportunity to expand the knowledge base of employees which serves the organization in long term. Training programs are effective for increasing organizational performance by being affordable and highly visible methods, and customizable with instant returns (Clifford \& Thorpe, 2007). The immediate benefits of the training and development practices to a workplace are improved employee performance, greater job satisfaction and morale in the workforce, addressing and eradicating weaknesses, reduced employee turnover and a substantial enhancement in company's reputation and brand equity. The quality of current workforce can be improved by organizations on providing comprehensive and updated training and development activities. Investment in training produces beneficial outcomes for any organization (Orpen, 1997). It is thus easily deduced that training and development practices can have a significant role to play in boosting organizational performance, particularly in hotel industry.

Hypothesis 2: There is no significant impact of career development practices on the organizational performance of hospitality sector.

Career development practices of luxury and budget hotel was found to be significantly and positively related to the Return on Assets, Return on equity and Growth in guest arrival. Thus the null hypothesis is rejected and it can be said that there is a significant impact of career development practices on the organizational performance of hospitality sector in the region. The concept of looking at an individual's career in its entirety and designing different sets of activities and relationships at each stage is called as career development (Wang \& Noe, 2010). These are developmental assignments that promote employees to move their way upward in the organization. Such practices include exposure of employees to new challenges to uncover their potential, and tempt them towards developing talent to reach better professional heights. It requires a more deliberate use of lateral moves and temporary assignments in hopes of leader development (McCauley, 2004; Yost \& Plunkett, 2009). 
Pushing talent development to the side will negatively impact the overall organizational effectiveness and performance (Maycock \& Ikuomola, 2015). Other practices include job rotations, job mobility and transfers, project assignments and real dilemma exposures. As per Natacha et al., (2014) these exposures provide talent with the opportunities to experience organizational, cultural and work practice situations. Challenging assignments result in practical, on-the-job learning (McCauley et al., 1998; DeRue and Wellman, 2009; Nyamori, 2015). It can hence be said that career development practices have a significant relationship with organizational performance.

Hypothesis 3: There is no significant impact of performance appraisal practices on the organizational performance of hospitality sector.

Performance appraisal practices of luxury and budget hotel was found to be significantly and positively related to the Return on Assets, Return on equity and Growth in guest arrival. Thus the null hypothesis is rejected and it can be said that there is a significant impact of performance appraisal on the organizational performance of hospitality sector in the region. Another important talent development practice that was seen to be adopted in all hotels surveyed in this study was performance appraisal systems. Appraisal and feedback systems have historically occurred as part of human interaction in organizations. It has majorly been used to furnish information about the company's immediate goals and to guide the employee's future behaviour in that regard. Honest feedback about one's behaviours, competencies, and impact on others is infrequent and inconsistent in many organizations.

However, effective feedback leads to a smooth flow of organizational goals from the top brass management to the employees, boosts creativity, promotes trusts, and drives motivation (Baker et al., 2013). With the hospitality sector being a highly labour intensive industry (Grobler \& Diedericks, 2009), there is complete stress upon the need to ensure regular feedback mechanisms on an employee's performance. Hotels must introduce healthy performance appraisals that are inspiring to the employees for critically evaluating and raising the standards of their performance. There is a high positive correlation between performance appraisal and organizational performance.

Hypothesis 4: There is no significant impact of mentoring practices on the organizational performance of hospitality sector.

Mentoring practices of luxury and budget hotel was found to be significantly and positively related to the Return on Assets, while it was found to have an insignificant relationship with the Return on equity and Growth in guest arrival. Thus the null hypothesis is rejected and it can be said that there is a significant impact of mentoring practices on the organizational performance of hospitality sector in the region. The study has shown that mentoring is also a widely prevalent talent development practice in the hospitality industry. As per Mangusho et al., (2015), leadership strategies and skills are necessary to elevate the employee spirit and induct them into challenges of the job. This challenge results in developmental relationships like mentors and coaches that are supportive to the employee and aid in the development of talent, usually when in a new work environment. These relationships can be particularly powerful drivers of learning and development because they are a rich source of assessment, challenge and support (McCauley and Douglas, 2004). Mentorship can also be in form of work communitybuilding (Boudreau et al., 2003; Wenger et al., 2002). Today mentoring is a common practice among companies to hone the talents of younger subordinates.

These relationships may be naturally occurring, arise through informal practices, or be intentionally developed through formal internship programs (Pittenger \& Heimann, 2000). Many organizations have begun to adopt formal mentoring programs 
as a way to develop their workforce (Douglas \& McCauley, 2004). As per Allen and O'Brien (2006), prospective employees are more attracted to an organization with a formal mentoring program than to one without such a program.

Hypothesis 5: There is no significant impact of recognition and award practices on the organizational performance of hospitality sector.

Recognition and award practices of luxury and budget hotel was found to be insignificantly but positively related to the Return on Assets, Return on equity and Growth in guest arrival. Thus the null hypothesis is accepted and it can be said that there is no significant impact of recognition and award practices on the organizational performance of hospitality sector in the region. A common practice used by employers and managers in attempt to promote talent development is the recognition and award method. Under this method, employers present incentives of either financial nature such as high performance bonus or otherwise to motivate employees to perform better. This is a way to honour employees for their contribution into the organization and is supposed to boost their morale as well as productivity .

It involves the setting up of a well-framed criterion for awards. This criterion for awards must also be in tune with the organization's overall goals and missions. A company's recognition and award program may include professional benefit for employees, supervisors and student workers; as well as, formal and informal recognition methods. Some common criteria for rewards and recognition programs followed by companies are performance of the employee in a set period, effort contributed by the employee towards achieving organizational objectives, seniority and loyalty to the company's growth, portfolio of skills of the employee and the complexities of the tasks demanded from the employee. However, recognition and awards system often can lead to more harm than good. Researchers have found that high performance bonus systems are more likely to encourage misrepresentation of performance and other strategic behaviours than to recognize and motivate exceptional performance or performance improvements (Heinrich, 2007). In the light of these cons, it has been found that recognition ad awards system is often detrimental to organizational performance and does not share a significantly positive relationship.

\section{CONCLUSION}

The objective of the present study has been three-fold; one, to identify the various talent development practices adopted for middle management in luxury and budget hotels; two, to measure the effectiveness of these practices from the perspective of managers and employers; and three, to identify if there exists a relationship between the effectiveness of talent development practices and overall organizational growth.

Researchers have chosen to conduct primary study across a total of 70 hotels across seven major Asian countries. The results of the study pointed out that there were a total of 25 widely identified practices across luxury and budget hotels, out of which 5 practices were found to be most commonly adopted. These five pervasive practices for talent development were; training and development of employees, career development opportunities, performance appraisal at regular intervals, proper mentoring, and recognition and awards for encouraging talented employees.

From the data collected from hotel managers, it can be concluded that talent development practices had greater effectiveness in luxury hotels as compared to budget hotels. Lastly, it can be concluded from the results of regression analysis that four out of the five identified talent development practices i.e. training programs, mentoring, performance appraisals and career development practices, had a 
significant relationship with organizational performance, based on return on assets (ROA), return on equity (ROE) and growth in guest arrival over five years from 20122017. However, the practice of financial rewards and recognition system did not have a significant relationship with organizational performance.

\section{PRACTICAL IMPLICATIONS}

The study will be a helpful aid for hoteliers and managers to understand popularly practiced talent development strategies that are helpful to the growth of the organization. The study is of importance to recruiters and trainers to devise their talent development strategy that suits their organizations' purpose the best. The study highlighted that out of five major talent development practices namely; training \&development, career development, performance appraisal, mentoring and recognitions and award, training \& development and performance appraisal were found to have a positive and significant impact on the organizational performance.

Hence, hoteliers are suggested to focus on the training and development of their employees, which can make them more skilled and updated and it can boost their selfconfidence, which will have a direct impact on their performance and on the overall organizational performance. Similarly; performance appraisal was considered as important practices, as employees whose performance are evaluated on regular basis and without any bias feel motivated and enthusiast to achieve their assigned targets, which leads to effective job performance and organizational performance too.

\section{RESEARCH LIMITATIONS}

The researchers have surveyed seven countries with major tourist destinations in Asian region, and chosen to ignore other countries that fall in this geographical ambit. For a wider understanding, hospitality sector in other countries may be studied by future researchers. The study may even be further expanded to pan-global level, and not merely Asia. The researchers have used regression model to analyze the impact of development practices on organizational performance. The researcher makes use of only three dependent variables or parameters in the regression model adopted in this study. Future researchers may be interested in exploring the relationship between talent development practices and organizational performance with addition of more parameters that are relevant to the study, such as retention rate and service quality variables.

\section{REFERENCES}

Aguinis, H. \& Kraiger, K. (2009). Benefits of training and development for individuals and teams, Organizations, and society. Annual review of psychology, 6o, pp.451-474.

Ahammad, S., (2013). Importance of Training in Hotel industry. Master's Thesis. Sodertorns University.

Allen, T.D. \& O'Brien, K.E. (2006). Formal mentoring programs and organizational Attraction. Human Resource Development Quarterly, 17(1), pp.43-58.

Baker, A., Perreault, D., Reid, A. \& Blanchard, C.M. (2013). Feedback and organizations: Feedback is Good feedback-friendly culture is better. Canadian Psychology/PsychologieCanadienne, 54(4), p.260.

Barlow, L. (2006). Talent development: the new imperative? Development and learning in Organizations: an international journal, 2o(3), pp.6-9.

Baum, T. (2015). Human resources in tourism: Still waiting for change? -A 2015 reprise. Tourism Management, 50, pp.204-212.

Benabou, C. \& Benabou, R. (1999). Establishing a formal mentoring program for organizational Success. National Productivity Review, 18(2), pp.7-14.

Berger, L.A. \& Berger, D.R. (2003). The talent management handbook: Creating organizational Excellence through identifying developing and positioning your best people. 
Boudreau, J., Hopp, W., McClain, J.O. \& Thomas, L.J. (2003). On the interface between operations and human resources management. Manufacturing \& Service Operations Management, 5(3), pp.179-202.

Brewster, C. (2007). Comparative HRM: European views and perspectives. The International Journal of Human Resource Management, 18(5), pp.769-787.

Brown, P. \& Tannock, S. (2009). Education, meritocracy and the global war for talent. Journal of Education Policy, 24(4), pp.377-392.

Cascio, W. F. (2015). Managing human resources. McGraw-Hill.

Cheese, P. (2008) .Driving high performance in the talent-powered organization. Strategic HR Review, $7(4)$, pp.25-31.

Claussen, J. Grohsjean, T., Luger, J. \& Probst, G., (2014). Talent management and career Development: What it takes to get promoted. Journal of World Business, 49(2), pp.236-244.

Clarke, R \& Winkler, V. (2006). Reflections on Talent Management. London: CIPD.

Clifford, J. \& Thorpe, S. (2007). Workplace learning \& development: Delivering competitive Advantage for your organization. Kogan Page Publishers.

Coleman, J.S., (1987). Families and schools. Educational researcher, 16(6), pp.32-38.

Delaney, J.T. \& Huselid, M.A. (1996). The impact of human resource management practices on Perceptions of organizational performance. Academy of Management journal, 39(4), pp.949-969.

DeRue, D.S. \& Wellman, N. (2009). Developing leaders via experience: the role of developmental Challenge, learning orientation, and feedback availability. Journal of Applied Psychology, 94(4), p.859.

Ellinger, A.D., Ellinger, A.E., Yang, B. \& Howton, S.W. (2002). The relationship between the learning Organization concept and firms' financial performance: An empirical assessment. Human resource development quarterly, 13(1), pp.5-22.

Ford, J., Harding, N. \& Stoyanova Russell, D. (2010). Talent management and development. An Overview of current theory and practice.

Frank, F.D., Finnegan, R.P. \& Taylor, C.R. (2004). The race for talent: Retaining and engaging Workers in the 21st century. Human Resource Planning, 27(3).

Garavan, T.N., Carbery, R. \& Rock, A. (2012). Mapping talent development: definition, scope and Architecture. European journal of training and development, 36(1), pp.5-24.

Gladwell, M., (2010). Talent grab: why do we pay our stars so much money? New Yorker, p.84.

Grobler, P.A. \& Diedericks, H. (2009). Talent management: An empirical study of selected South African hotel groups. Southern African Business Review, 13(3).

Heinrich, C.J. (2007). False or fitting recognition? The use of high performance bonuses in motivating Organizational achievements. Journal of Policy Analysis and Management: The Journal of the Association for Public Policy Analysis and Management, 26(2), pp.281-304.

Huang, T.C. (2001). The relation of training practices and organizational performance in small and Medium size enterprises. Education+ Training, 43(8/9), pp.437-444.

Iles, P., Preece, D. \& Chuai, X. (2010). Talent management as a management fashion in HRD: Towards a research agenda. Human Resource Development International, 13(2), pp.125-145.

Kim, S. \& McLean, G.N. (2012). Global talent management: Necessity, challenges, and the roles of HRD. Advances in Developing Human Resources, 14(4), pp.566-585.

Kraimer, M.L., Seibert, S.E., Wayne, S.J., Liden, R.C. \& Bravo, J. (2011). Antecedents and outcomes of organizational support for development: The critical role of career opportunities. Journal of Applied Psychology, 96(3), p.485.

Latukha, M.O. (2018). Talent development and a firm's performance: Evidence from Russian Companies. Journal of General Management, 43(2), pp.51-62.

Lawler, E.E. (2008). Strategic talent management: Lessons from the corporate world. Strategic Management of Human Capital, (5), pp.1-35.

Lehmann, S. (2009). Motivating talents in Thai and Malaysian service firms. Human Resource Development International, 12(2), pp.155-169.

Lewis, R.E. \& Heckman, R.J. (2006). Talent management: A critical review. Human resource Management review, 16(2), pp.139-154.

Lockwood, N.R. (2006). Talent management: Driver for organizational success. HR magazine, 51(6), Pp.1-11.

Magd, H. (2003). Management attitudes and perceptions of older employees in hospitality Management. International Journal of Contemporary Hospitality Management, 15(7), pp.393-401.

Malhotra, S. (2017). Hospitality Industry in India: A Big Contributor to Economy's Growth. BW-Business World. Published 16 May 2017.Accessed 13 November 2018.

Mangusho, Y.S., Murei, R.K. \& Nelima, E. (2015). Evaluation of Talent Management on Employees Performance in Beverage Industry: A Case of Delmonte Kenya Limited. International Journal of Humanities and Social Science, 5(8), pp.191-199.

Mariela Natacha \& Golik, María Rita Blanco, (2014) "Talent identification and development tools: Two to tango?", Management Research: The Journal of the Iberoamerican Academy of Management, Vol. 12 Issue: 1, pp.23-39, https://doi.org/10.1108/MRJIAM-01-2013-0498. 
Maurer, T.J., Mitchell, D.R. \& Barbeite, F.G. (2002). Predictors of attitudes toward a 36odegree Feedback system and involvement in post feedback management development activity. Journal of Occupational and Organizational Psychology, 75(1), pp.87-107.

Maycock, E.A. \& Ikuomola, O.A. (2015). Learning and talent development: a review in Context. International Journal of Advanced Research in Engineering \& Management (IJAREM), pp.98-111.

McCauley, C. \& Douglas, C. (2004), "Developmental relationships", in McCauley, C. and Velsor, E (Eds), The Center for Creative Leadership Handbook Leadership Development, 2nd ed., Jossey-Bass, San Francisco.

McCauley, C., Moxley, R. \& Van Velsor, E. (1998), TheCenter for Creative Leadership Handbook of Leadership Development, John Wiley \& Sons, San Francisco.

McDonnell, A. (2011). Still fighting the "war for talent"? Bridging the science versus practice Gap. Journal of Business and Psychology, 26(2), 169-173.

Michaels, E., Handfield-Jones, H. \& Axelrod, B., (2001). The war for talent. Harvard Business Press.

Nilsson, S. \& Ellström, P.E. (2012). Employability and talent management: challenges for HRD Practices. European Journal of Training and Development, 36(1), pp.26-45.

Nyamori, S. (2015). The Effect of Workplace Mentoring on Employee Performance: A Case Study of SOS Children's Villages (Doctoral dissertation, United States International University-Africa).

Orpen, C. (1997). The effects of formal mentoring on employee work motivation, organizational Commitment and job performance. The Learning Organization, 4(2), pp.53-6o.

Pittenger, K.K. \& Heimann, B.A. (2000). Building effective mentoring relationships. Review of Business, 21(1/2), p.38.

Rhodes, C., Brundrett, M., \& Nevill, A. (2008). Leadership talent identification and development: Perceptions of heads, middle leaders and classroom teachers in 70 contextually different primary and secondary schools in England. Educational Management Administration \& Leadership, 36(3), 311-335.

Rothwell, W.J. \& Kazanas, H.C. (2004). Improving on-the-job training: How to establish and Operate a comprehensive OJT program. John Wiley \& Sons.

Scott, B. \& Revis, S. (2008). Talent management in hospitality: graduate career success and Strategies. International Journal of Contemporary Hospitality Management, 20(7), pp.781-791.

Scullion, H. \& Collings, D. (2011). Global talent management. Routledge.

Seibert, S. 1999. The effectiveness of facilitated mentoring: A longitudinal quasi-experiment. Journal of Vocational Behavior, 54(3), pp.483-502.

Sheehan, M. (2012). Developing managerial talent: Exploring the link between management talent and Perceived performance in multinational corporations (MNCs). European Journal of Training and Development, 36(1), pp.66-85.

Singh, D.A. (2018). Talent Management-A challenge for Indian Industries.

Stahl, G.K., Björkman, I., Farndale, E., Morris, S.S., Paauwe, J., Stiles, P., Trevor, J. \& Wright, P.M., (2007). Global talent management: How leading multinationals build and sustain their talent pipeline. INSEAD faculty and research working papers, 24 (1), p. 08.

Stewart, J. \& Harte, V. (2010). The implications of talent management for diversity training: An Exploratory study. Journal of European Industrial Training, 34(6), pp.506-518.

Sumardi, W.A. \& Othman, R. (2009). The three faces of talent management in Malaysia. International Journal of Business Research, $10(1)$, pp.181-185.

Tansley, C. (2011). What do we mean by the term "talent" in talent management? Industrial and Commercial training, 43(5), pp.266-274.

Thijssen, J.G.L. \& van Heijden, B.D. (2003). Evaporated talent? Problems with talent development During the career. International Journal of Human Resources Development and Management, 3(2), pp.154-170.

Wang, S. \& Noe, R.A. (2010). Knowledge sharing: A review and directions for future Research. Human resource management review, $20(2)$, pp.115-131.

Wenger, E., McDermott, R.A. \& Snyder, W. (2002). Cultivating communities of practice: A guide to Managing knowledge. Harvard Business Press.

Yost, P.R. \& Plunkett, M.M. (2009). Real time leadership development (7 Edn). John Wiley \& Sons.

Submitted:

14.05.2019
Revised:

27.09.2019
Accepted and published online 01.10.2019 